\title{
Stable isotopes reveal inter-annual and inter-individual variation in the diet of female Australian fur seals
}

\author{
J. P. Y. Arnould ${ }^{1, *}$, Y. Cherel ${ }^{2}$, J. Gibbens ${ }^{3}$, J. G. White ${ }^{1}$, C. L. Littnan ${ }^{4}$ \\ ${ }^{1}$ School of Life and Environmental Sciences, Deakin University, 221 Burwood Highway, Burwood, Victoria 3125, Australia \\ ${ }^{2}$ Centre d'Etudes Biologiques de Chizé, UPR 1934 du CNRS, BP 14, 79360 Villiers-en-Bois, France \\ ${ }^{3}$ Department of Zoology, University of Melbourne, Parkville, Victoria 3010, Australia \\ ${ }^{4}$ Pacific Island Fisheries Science Center (PIFSC), NOAA Fisheries, 2570 Dole Street, Honolulu, Hawaii 96822, USA
}

\begin{abstract}
Understanding the temporal and spatial variation of foraging habits of apex predators is central to understanding their role in marine ecosystems and how their populations may respond to environmental variability. In the present study, stable isotope analysis ( $\mathrm{C}$ and $\mathrm{N}$ ) of blood was used to investigate inter-individual and inter-annual differences in the diet of adult female Australian fur seals Arctocephalus pusillus doriferus. Positive correlations were observed between red cell and plasma values for $\delta^{13} \mathrm{C}$ and $\delta^{15} \mathrm{~N}\left(\mathrm{r}^{2}=0.47\right.$ and $\mathrm{r}^{2}=0.66$, respectively, $\mathrm{p}<0.001$ in both cases), suggesting relatively consistent individual prey choices over 3 or 4 foraging trips. Mean $\delta^{15} \mathrm{~N}$ values (12.8 to $17.5 \%$ ) confirm the species occupies the highest marine trophic niche in the region. A significant decrease in plasma $\delta^{15} \mathrm{~N}$ values, corresponding to two-thirds of a trophic level (ca. $2 \%$ ), was observed between the 1998 to 2000 and 2003 to 2005 sampling periods. This was associated with a significant decrease in adult female body condition and is consistent with a decline, previously documented by faecal analysis, of the proportion of red cod Pseudophysis bachus, barracouta Thyrsites atun and Gould's squid Nototodarus gouldi in the diet and an increase in redbait Emmelichthys nitidus. While substantial variation in $\delta^{15} \mathrm{~N}$ was observed within each age cohort, a significant decrease was observed with age, suggesting individual specialisation for particular prey types is evident early in adulthood, but that its composition changes as females age. In addition, generalized linear models indicated body mass had a negative influence on $\delta^{15} \mathrm{~N}$, which may reflect larger total body oxygen stores, facilitating individuals hunting cryptic prey of lower trophic level (e.g. octopus) on the sea floor.
\end{abstract}

KEY WORDS: Australian fur seal $\cdot$ Otariid $\cdot$ Stable isotopes $\cdot$ Diet $\cdot$ Bass Strait $\cdot$ Arctocephalus pusillus doriferus

Resale or republication not permitted without written consent of the publisher

\section{INTRODUCTION}

Marine ecosystems are highly dynamic, changing on a range of spatial and temporal scales under a variety of influences (Bertram et al. 2001, Misarti et al. 2009). Detecting such changes may be challenging at times, due to the complex trophic interactions that occur and the logistical restrictions that limit the range and extent to which oceanic regions can be feasibly sampled (Fulton et al. 2004). Marine apex predators such as pinnipeds (seals and sea lions) and seabirds, how- ever, provide practicable and convenient means of monitoring marine ecosystem variability (Boyd \& Murray 2001). Because these species must return to land to breed and raise young, their foraging parameters (e.g. diet, hunting behaviour) and the corresponding biological consequences (e.g. reproductive output, offspring growth rates) can be readily sampled. For example, monitoring of Antarctic fur seal Arctocephalus gazella faeces has revealed inter-annual and geographic variation in the growth rate and composition of krill Euphausia superba populations (Reid et al. 
1999), while the foraging behaviour and reproductive performance of fur seals, penguins and other seabirds have been used to infer the spatial distribution and abundance of this keystone prey species (Reid et al. 2005). Knowledge of how the diets and foraging behaviour of apex predators spatially and temporally vary, however, is also integral to predicting how their populations may respond to environmental perturbations, both natural and anthropogenic, in resource availability (Lea et al. 2006, Rolland et al. 2009).

The Australian fur seal Arctocephalus pusillus doriferus, the largest of the fur seal species, has a breeding distribution restricted to just 13 sites, all but one occurring within Bass Strait, in south-eastern Australia (Kirkwood et al. 2010). With mean adult female and male body masses of 76 and $229 \mathrm{~kg}$, respectively (Arnould \& Warneke 2002), and a current estimated population size of ca. 120000 , the species represents the largest predator biomass in the marine ecosystem of the region (Goldsworthy et al. 2003). In addition, several studies have demonstrated that the foraging range of the species is restricted to the shallow continental shelf (mean maximum depth $<100 \mathrm{~m}$ ) of Bass Strait such that its impact is locally concentrated (Arnould \& Hindell 2001, Arnould \& Kirkwood 2007). Consequently, the influence of Australian fur seals on the trophic dynamics of the region, and how this varies with environmental fluctuations, is of significant ecological interest and critical for understanding how the species, and its prey populations, may respond to changing climatic and oceanographic conditions.

Using faecal analysis, several studies across the species' range have documented that the diet of Australian fur seals consists predominantly of fish, e.g. redbait Emmelichthys nitidus, barracouta Thyrsites atun, jack mackerel Trachurus declivis, red cod Pseudophysis bachus and leatherjacket (family Monocanthidae), as well as of Gould's squid Nototodarus gouldi (Gales et al. 1993, Gales \& Pemberton 1994, Hume et al. 2004, Page et al. 2005, Littnan et al. 2007, Kirkwood et al. 2008). These studies, however, have all demonstrated that Australian fur seals regularly consume a wide variety of prey ( 43 to 49 species) and that the species is a generalist predator (Littnan et al. 2007). This has been further highlighted in a recent analysis of faecal DNA, which, while confirming the identity of the documented species predominantly consumed, demonstrated an even greater array of prey ( $>62$ species) than previously identified (Deagle et al. 2009).

From analysis of faecal samples collected over a 9 yr period, Kirkwood et al. (2008) documented a major inter-annual shift in Australian fur seal diet composition. A multi-year increase in the frequency of occurrence of redbait coincided with decreases in red cod and barracouta, as well as a reduction in the size of Gould's squid. This change was associated with colder sea surface temperatures (SST) in the foraging areas in the western Bass Strait, suggesting oceanographic influences on the availability and abundance of prey (Kirkwood et al. 2008). The limitations and inherent biases of faecal analysis (Dellinger \& Trillmich 1988, Gales \& Cheal 1992), however, restrict inferences about how observed changes in prey remains reflect changes in prey biomass consumption, especially in generalist predators like Australian fur seals, which consume such a wide variety of prey (Arim \& Naya 2003). Furthermore, there is currently no information on inter-individual variation in the diet of this species, e.g. it is not known whether the observed diet changes are uniform or limited to particular age or sex classes, factors important for determining population responses to environmental variability (Winship et al. 2002).

Over the last decade, analysis of the stable isotope ratios of $\mathrm{C}\left({ }^{13} \mathrm{C} /{ }^{12} \mathrm{C}\right)$ and $\mathrm{N}\left({ }^{15} \mathrm{~N} /{ }^{14} \mathrm{~N}\right)$ in tissues has increasingly been used to investigate various aspects of foraging ecology in marine mammals. Information on trophic position, spatial variation in diet and geographic sources of prey has been obtained for a variety of species (e.g. Huckstadt et al. 2007, Porras-Peters et al. 2008). Seasonal, inter-annual and decadal differences in diet have also been detected and related to fluctuations in prey availability and oceanographic conditions (e.g. Hall-Aspland et al. 2005b, Drago et al. 2009b, Hanson et al. 2009). In addition, in conjunction with data on prey values, estimates of the relative contribution of various prey species to biomass consumption have been obtained (Hall-Aspland et al. 2005a, Hammill et al. 2005, Huckstadt et al. 2007), as well as evidence of ontogenetic and inter-individual variation in niche breadth (Tucker et al. 2007, Drago et al. 2009a, Newsome et al. 2009).

There are currently few data on stable isotope values in Australian fur seals; thus, it is not possible at present to use this technique to monitor temporal or geographic variation in diet, or to estimate relative biomass contributions of prey, in this species (Davenport \& Bax 2002). Furthermore, it is not possible to assess the degree of inter-individual variation in niche breadth (Newsome et al. 2009). While the Australian fur seal is considered a generalist predator, it is not known whether the population is comprised of generalists or an array of specialist individuals, as has been observed in some other otariid species (Villegas-Amtmann et al. 2008). The aims of the present study, therefore, were to assess whether stable isotope analyses could be used to detect inter-annual, spatial and interindividual variation in the trophic position of female Australian fur seals. 


\section{MATERIALS AND METHODS}

Field procedures. The study was conducted primarily at the Australian fur seal Arctocephalus pusillus doriferus breeding colony on Kanowna Island $\left(39^{\circ} 10^{\prime} \mathrm{S}, 146^{\circ} 18^{\prime} \mathrm{E}\right)$, central northern Bass Strait (Fig. 1), between May and October each year during 2 sampling periods (1998 to 2000 and 2003 to 2005). Additional samples were collected from a breeding colony at The Skerries $\left(37^{\circ} 45^{\prime} \mathrm{S}, 149^{\circ} 31^{\prime} \mathrm{E}\right)$ in eastern Bass Strait, at the eastern extent of the species' breeding range (Kirkwood et al. 2005), between April and October in 1999 and 2000. Together, these colonies account for $24 \%$ of the total species population (Kirkwood et al. 2010). The samples were collected opportunistically during other concurrent studies (Arnould \& Hindell 2001, Littnan 2003, Gibbens et al. 2010).

Adult females selected at random were captured using a modified hoop-net (Fuhrman Diversified). Upon capture, an intra-muscular injection (ca. $0.15 \mathrm{mg}$ $\mathrm{kg}^{-1}$ ) of the sedative Midazolam (Hypnovel, Roche) was administered to facilitate handling and reduce capture stress. Once sedated, individually numbered plastic tags (Super Tags, Dalton I.D. Systems) were placed in the trailing edge of each fore-flipper and a single blood sample $(5 \mathrm{ml})$ was collected into a heparinised syringe (S-Monovette, Sarstedt SA) by venipuncture of a small inter-digital vein in a hind-

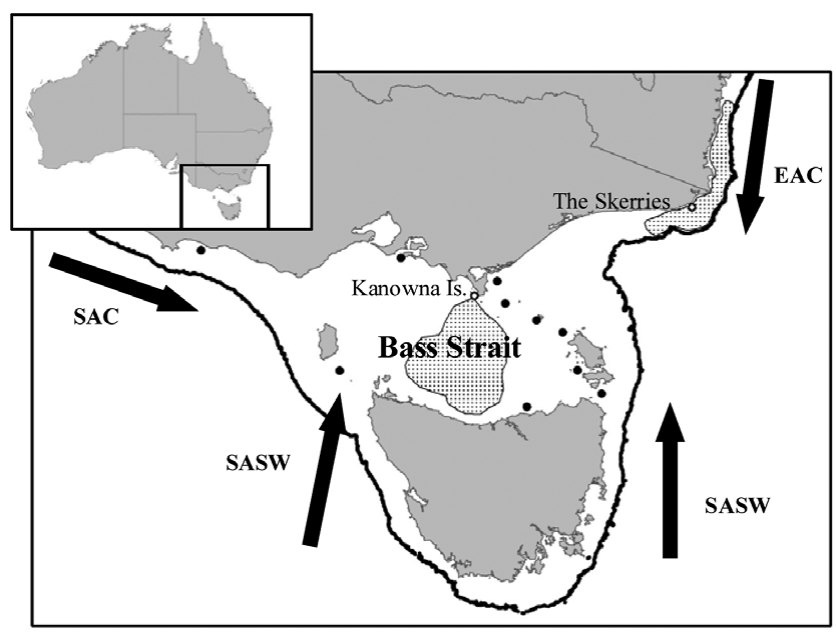

Fig. 1. Map of south-eastern Australia showing Kanowna Island and The Skerries, both Australian fur seal Arctocephalus pusillus doriferus breeding colonies (open circles), where blood samples were collected from adult female seals. The foraging regions of females from these 2 colonies is indicated by the stippled areas. The other Australian fur seal breeding colonies (filled circles) and the major currents influencing oceanographic conditions within Bass Strait are also shown. Solid line indicates $200 \mathrm{~m}$ bathymetric contour (continental shelf edge). EAC: East Australia Current; SAC: South Australian Current; SASW: Subantarctic Surface Water flipper. Blood samples were kept cool $\left(4^{\circ} \mathrm{C}\right)$ for several hours before being centrifuged and were separated into plasma and red cell fractions. For samples collected at The Skerries, both fractions were retained, whereas, for samples from Kanowna Island, only red cell and then only plasma fractions were retained during the 1998 to 2000 and 2003 to 2005 sampling periods, respectively. The separated blood fractions were stored frozen at $-20^{\circ} \mathrm{C}$ until analysis in the laboratory.

During the 2003 to 2005 sampling period, individuals were also maintained on isoflurane gas anaesthesia throughout the handling procedures (Gales \& Mattlin 1998). The presence of a pup was noted before capture, and, after blood samples were collected, females not observed with a pup were checked for lactation status by manual expression of the teats following injection of oxytocin (0.5 to $1.0 \mathrm{ml}, 10 \mathrm{UI} \mathrm{ml}^{-1}$; Heriot Agvet) to stimulate milk release. Individuals were then weighed (body mass, BM) on a flat platform using a spring scale $(200 \pm 0.5 \mathrm{~kg}$; Salter) and measured for standard length (STDL) and fore-flipper length (FL) using a metal tape measure $( \pm 0.5 \mathrm{~cm})$. Following injection of local anaesthetic (10 mg lignocaine hydrochloride; Xylocaine, AstraZeneca) into the gum, dental elevators were used to extract a lower first post-canine tooth for age determination from annual cementum lines (Arnbom et al. 1992). Extracted teeth were stored in $70 \%$ ethanol until thin-sectioning, staining and examination under transmitted light (polarising filter) on a stereo microscope $(4 \times$ to $10 \times$ ) in the laboratory following the methods described by Gibbens \& Arnould (2009a).

To investigate potential relationships between interannual variation in trophic position and food availability, the condition of all adult females captured (as part of this and concurrent studies) was determined. Individual female body condition was estimated using a body condition index (BCI) that has been correlated with blubber depth in Australian fur seals (Arnould \& Warneke 2002). Using data for all adult females captured between May and October in the years from 1998 to 2009 at Kanowna Island, BM was regressed against STDL using a power function, and each individual's residual value was taken as its BCI (Arnould \& Warneke 2002). Mean BCI was then calculated for each year of stable isotope sampling.

Laboratory procedures, calculations and statistical analyses. In the laboratory, aliquots of the thawed plasma and red cell fractions were dried in an oven at $60^{\circ} \mathrm{C}$ and ground to a fine powder. The powdered red cells were rinsed with hexane in a capillary tube stuffed with glass wool to remove any lipids (Smedes 1999). After 3 rinses, the red cells were transferred to a glass vial and dried in a vacuum oven at $60^{\circ} \mathrm{C}$ for $24 \mathrm{~h}$ to remove any remaining solvent. Sub-samples (ca. $1.5 \mathrm{mg}$ ) of the powdered plasma and red cell frac- 
tions were then loaded into tin capsules and were combusted at $1000^{\circ} \mathrm{C}$ in a CHN elemental analyser (CE1110, Carlo Erba). The resultant $\mathrm{CO}_{2}$ and $\mathrm{N}_{2}$ gases were analysed using an interfaced Fisons isochrom continuous-flow isotope ratio mass spectrometer (GV Instruments), with unknowns separated by laboratory standards. Analyses were conducted in the Environmental Biology Group laboratory at the Research School of Biology, Australian National University (Canberra, Australia).

Stable isotope abundances were expressed in $\delta$-notation as the deviation from standards in parts per thousand (\%o) according to the following equation:

$$
\delta X=\left[\left(R_{\text {sample }} / R_{\text {standard }}\right)-1\right] \times 1000
$$

where $X$ is ${ }^{13} \mathrm{C}$ or ${ }^{15} \mathrm{~N}$ and $R$ is the corresponding ratio of ${ }^{13} \mathrm{C} /{ }^{12} \mathrm{C}$ or ${ }^{15} \mathrm{~N} /{ }^{14} \mathrm{~N}$. $R_{\text {standard }}$ values were based on PeeDee Belemnite for ${ }^{13} \mathrm{C}$, or atmospheric nitrogen $\left(\mathrm{N}_{2}\right)$ in air for ${ }^{15} \mathrm{~N}$. Replicate measurements of laboratory standards showed measurement errors of $\pm 0.1 \%$ and $\pm 0.3 \%$ for stable carbon and nitrogen isotope measurements, respectively. Quality control samples were run before and after each sequence.

To investigate the potential impact of pregnancy on isotope values, aliquots of the 2003 to 2005 plasma samples were also assayed using coated-tube radioimmunoassay kits (Spectria, Progesterone RIA, Orion Diagnostica) for progesterone concentration to determine pregnancy status as described by Gibbens et al. (2010). Briefly, the organic component of each sample of plasma was extracted with ethyl acetate, then resuspended in water to achieve a 1:4 dilution. A $50 \mu \mathrm{l}$ aliquot of diluted extract was added to duplicate polyclonal (rabbit) progesterone antibody-coated assay kit tubes with $500 \mu \mathrm{l}$ of ${ }^{125} \mathrm{I}$-progesterone and was incubated for $2 \mathrm{~h}$ at room temperature before measurement. Samples with progesterone concentrations of $\geq 3.1 \mathrm{ng} \mathrm{ml}^{-1}$ were considered indicative of pregnancy.

Using SPSS (Version 17.0 for Windows, SPSS), differences between tissues, locations and years were tested by analysis of variance (ANOVA) after assessing data for normality (Kolmogorov-Smirnov test) and Levene's test for homogeneity of variances (F-test). Tukey's post hoc tests were conducted to determine homogenous subsets. Where data were not normally distributed, appropriate non-parametric tests were used. Unless otherwise stated, data are presented as means $( \pm 1 \mathrm{SE})$ and results are considered significant at the $\mathrm{p}<0.05$ level.

For the 2003 to 2005 samples, the relationship between age and mean plasma $\delta^{15} \mathrm{~N}$ and $\delta^{13} \mathrm{C}$ values was tested using a weighted regression. An informationtheoretic approach, as described by Burnham \& Anderson (2002), was then taken to examine the influence of all measured individual characteristics after they were tested for multicollinearity (Zar 1984). As the present study had a relatively small sample size for the number of variables used and the data were not over-dispersed, the second order Akaike information criterion corrected for small sample sizes (AICc) was utilised. Generalized linear models using a Gaussian distribution were used to investigate the relationship between both $\delta^{15} \mathrm{~N}$ and $\delta^{13} \mathrm{C}$ in plasma and the predictor variables age $(\mathrm{yr}), \mathrm{BM}(\mathrm{kg})$, STDL $(\mathrm{cm}), \mathrm{FL}(\mathrm{cm})$ and the ratio FL/STDL, a factor which can influence manoeuvrability (Fish et al. 2003, Cheneval et al. 2007).

Akaike differences ( $\triangle \mathrm{AIC}$ ) were used to determine the level of support for each model in the candidate set. Burnham \& Anderson (2002) suggest that candidate models with Akaike differences of $<2$ have substantial support for being the best of the candidate set of models. Akaike weights $\left(\omega_{i}\right)$ were additionally used to determine the evidence of support for each model. Akaike weights are the proportional weight of evidence in support of the particular model being the best model for the situation (Burnham \& Anderson 2002). Summed AIC weights were also used to help identify influential predictor variables in the models. The AIC weights are summed for all models that include a particular variable, with a highly influential variable being able to have a maximum weight of 1 .

Model averaging was used to give unconditional model variances when the Akaike weight suggested no individual model was clearly the best of the candidate set of models $\left(\omega_{i}>0.9\right)$ (Anderson et al. 2001). Weighted model averaging based on 1000 bootstrapped samples was used to reduce model selection bias. Hierarchical partitioning was used to determine the independent contribution of each predictor variable to the overall model. Models were developed using R statistical packages (Ihaka \& Gentleman 1996), using algorithms to calculate AICc, bootstrap frequencies and model-averaged estimates (M. Scroggie, Arthur Rylah Institute of Environmental Research, Heidelberg, Victoria 3084 Australia, unpubl. data). Hierarchical partitioning was undertaken in $\mathrm{R}$ using the hier.part package (Walsh \& Mac Nally 2003).

\section{RESULTS}

\section{Temporal and spatial variation}

A total of 184 and 58 blood samples were collected from adult female Arctocephalus pusillus doriferus at Kanowna Island and at The Skerries, respectively (Table 1). There were no significant differences between seasons at either site for $\delta^{13} \mathrm{C}$ or $\delta^{15} \mathrm{~N}$ values ( $p>0.3$ in all cases), so data for all months were combined within years at each site. In the years when samples were collected at both sites (1999 to 2000), there 
Table 1. Arctocephalus pusillus doriferus. Summary of stable isotope values in blood (red cells and plasma) collected from adult female Australian fur seals at 2 breeding colonies (Kanowna Island and The Skerries) and the mean body condition index (BCI) of adult females in the sampling years (when available). See 'Materials and methods: Field procedures' for details of BCI calculation. Data are presented as means \pm SE. No BCI data were available for Kanowna Island in 2000 or The Skerries. The same superscripted letters represent homogenous subsets at $\mathrm{p}>0.05$

\begin{tabular}{|c|c|c|c|c|c|c|c|}
\hline \multirow[t]{2}{*}{ Location } & \multirow[t]{2}{*}{ Year } & \multirow[t]{2}{*}{$\mathrm{n}$} & \multicolumn{2}{|c|}{$\longrightarrow$ Red blood cells -} & \multicolumn{2}{|c|}{ Plasma } & \multirow{2}{*}{$\begin{array}{c}\text { Female } \\
\text { BCI }\end{array}$} \\
\hline & & & $\delta^{13} \mathrm{C}$ & $\delta^{15} \mathrm{~N}$ & $\delta^{13} \mathrm{C}$ & $\delta^{15} \mathrm{~N}$ & \\
\hline Kanowna Island & 1998 & 31 & $-18.5 \pm 0.1$ & $15.9 \pm 0.1$ & - & - & $8.27 \pm 1.83^{\mathrm{a}}$ \\
\hline Kanowna Island & 1999 & 21 & $-18.8 \pm 0.1$ & $15.7 \pm 0.1$ & - & - & $5.13 \pm 1.42^{\mathrm{a}}$ \\
\hline The Skerries & 1999 & 32 & $-18.3 \pm 0.1$ & $15.5 \pm 0.1$ & $-19.2 \pm 0.1$ & $16.1 \pm 0.1$ & - \\
\hline Kanowna Island & 2000 & 10 & $-18.2 \pm 0.1$ & $15.5 \pm 0.1$ & - & - & - \\
\hline The Skerries & 2000 & 26 & $-17.7 \pm 0.1$ & $15.3 \pm 0.1$ & $-18.6 \pm 0.1$ & $16.0 \pm 0.1$ & - \\
\hline Kanowna Island & 2003 & 28 & - & - & $-18.1 \pm 0.1$ & $14.2 \pm 0.1$ & $-0.18 \pm 0.78^{b}$ \\
\hline Kanowna Island & 2004 & 45 & - & - & $-18.2 \pm 0.1$ & $14.2 \pm 0.1$ & $0.18 \pm 0.08^{\mathrm{b}}$ \\
\hline Kanowna Island & 2005 & 49 & - & - & $-18.7 \pm 0.1$ & $13.8 \pm 0.1$ & $-1.77 \pm 0.71^{b}$ \\
\hline
\end{tabular}

were small, but significant, differences in isotope values between years and sites. Red cells were significantly more enriched in $\delta^{13} \mathrm{C}$ (2-way ANOVA: $F_{3,88}=$ 56.56, p < 0.0001) in $2000(+0.4 \%$ o) and at The Skerries $(+1.0 \%$ ). Conversely, red cells were more enriched in $\delta^{15} \mathrm{~N}\left(2\right.$-way ANOVA: $\left.F_{3,88}=20.43, \mathrm{p}<0.0001\right)$ in 1999 $(+0.3 \%)$ and at Kanowna Island $(+0.7 \%$ ) .

Both $\delta^{13} \mathrm{C}$ and $\delta^{15} \mathrm{~N}$ values in the plasma and red cell fractions from the same samples $(n=57)$ collected at The Skerries were positively correlated $\left(\mathrm{r}^{2}=0.47\right.$ and $\mathrm{r}^{2}=0.66$, respectively, $\mathrm{p}<0.001$ in both cases). Red cell $\delta^{13} \mathrm{C}$ (range: -19.3 to $-17.1 \%$ ) was more enriched (by $0.9 \pm 0.1 \%$ ), whereas plasma $\delta^{15} \mathrm{~N}$ (range: 14.2 to $16.4 \%$ ) was consistently enriched compared to red cells (by $0.6 \pm 0.1 \%$ ). Consequently, correction factors of $-0.9 \%$ and $+0.6 \%$ for $\delta^{13} \mathrm{C}$ and $\delta^{15} \mathrm{~N}$, respectively, were applied to the 1998 to 2000 Kanowna Island red cell values to enable comparison with those from the plasma samples collected in 2003 to 2005.

Overall, plasma $\delta^{13} \mathrm{C}\left(-20.5\right.$ to $-17.0 \%$ o) and $\delta^{15} \mathrm{~N}$ (12.8 to $17.5 \%$ ) values varied substantially at Kanowna Island, both within and between years. The coefficient of variation $(\mathrm{CV})$ within years was greater for $\delta^{13} \mathrm{C}$ (range: 0.3 to $2.8 \%$ ) than for $\delta^{15} \mathrm{~N}$ (range: 0.6 to $1.8 \%$ ). Previous studies have indicated that lipids in samples can negatively bias $\delta^{13} \mathrm{C}$ values in tissues as they are ${ }^{13} \mathrm{C}$-depleted (Deniro \& Epstein 1977) and that otariid blood can vary greatly in lipid content, especially in lactating females (Arnould et al. 2002). While lipids were not removed from plasma samples in the present study, the C:N ratio in samples ranged from 3.4 to 3.8, indicating that lipids are unlikely to have significantly affected the $\delta^{13} \mathrm{C}$ values (Cherel et al. 2005). Furthermore, comparison of replicates from a random sample ( $\mathrm{n}=12$ ) of red blood cells in which lipids were extracted and not removed found no significant differences in $\delta^{13} \mathrm{C}$ values (paired $t$-test: $t_{11}=0.673, \mathrm{p}=0.52$ ).

There were significant differences in both plasma $\delta^{13} \mathrm{C}$ and $\delta^{15} \mathrm{~N}$ between years at Kanowna Island. Plasma $\delta^{13} \mathrm{C}$ differed significantly between the 1998 to 2000 and 2003 to 2005 sampling periods (ANOVA: $F_{5,183}=47.26, \mathrm{p}<$ 0.001). Similarly, but less variable within the groupings, females in 1998 to 2000 were more enriched (ca. $2 \%$ ) in $\delta^{15} \mathrm{~N}$ than those in 2003 to 2004, which, in turn, were slightly more enriched (ca. 0.4\%) than those in 2005 (ANOVA: $F_{5,183}=235.83, \mathrm{p}<0.001$; Fig. 2). The mean $\delta^{13} \mathrm{C}$ and $\delta^{15} \mathrm{~N}$ values in each year were also negatively correlated $\left(\mathrm{r}^{2}=0.81, \mathrm{n}=5, \mathrm{p}=0.015\right)$.

The BCI of all adult females captured on Kanowna Island (Table 1) varied significantly between sampling years (ANOVA: $F_{4,287}=13.05, \mathrm{p}<0.001$ ), with individuals being in better condition from 1998 to 1999. Mean BCI was significantly positively correlated with mean $\delta^{15} \mathrm{~N}$ (Spearman's rank correlation: $\rho=0.80, \mathrm{n}=5, \mathrm{p}<$ 0.05). There was no correlation, however, between mean BCI and mean $\delta^{13} \mathrm{C}(\mathrm{p}=0.21)$. There were also no significant correlations between the mean $\delta^{15} \mathrm{~N}$ and $\delta^{13} \mathrm{C}$ values and observed total pup production (Gibbens \& Arnould 2009b) each year (Spearman's rank correlation: $\rho<0.60, n=5, p>0.5$ in both cases).

\section{Inter-individual variation}

The adult females sampled at Kanowna Island from 2003 to 2005 included individuals from a broad range of age, body mass and size classes (Table 2). Of the 111 individuals in which it could be determined, $81 \%$ were pregnant and/or $86 \%$ were lactating. Pregnant females (7.9 $\pm 0.4 \mathrm{yr})$ were significantly younger than nonpregnant individuals $\left(12.9 \pm 0.6 \mathrm{yr}, t_{109}=6.38, \mathrm{p}<\right.$ 0.001), but there was no significant difference between the ages of lactating and non-lactating females $\left(t_{19}=\right.$ $0.11, p=0.9$ ), nor were there differences in mean age between the 3 years dealt with in this sampling period $\left(F_{2,122}=3.01, \mathrm{p}=0.16\right)$. There were no significant differences in either $\delta^{13} \mathrm{C}$ or $\delta^{15} \mathrm{~N}$ values between pregnant and non-pregnant females ( $p>0.5$ in both cases). 


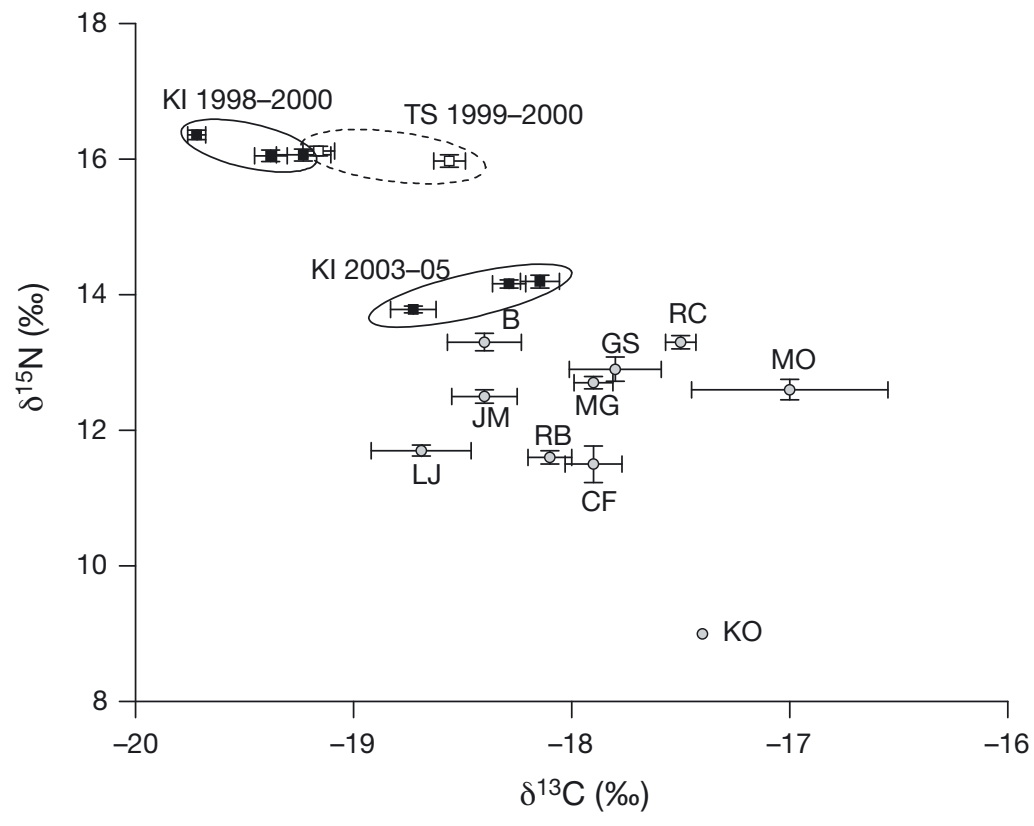

Fig. 2. Arctocephalus pusillus doriferus. $\delta^{13} \mathrm{C}$ and $\delta^{15} \mathrm{~N}$ values (mean $\pm \mathrm{SE}$ ) in plasma of adult female Australian fur seals collected at the Kanowna Island (KI) and The Skerries (TS) breeding colonies between the 1998 to 2000 and 2003 to 2005 sampling periods. The values for Kanowna Island from 1998 to 2000 were calculated from data on red blood cells (see 'Results: Temporal and spatial variation' for correction factors). The isotopic values of species consistently identified in faecal analyses as being the most important prey items of Australian fur seals are also provided (data obtained from Davenport \& Bax (2002). B: barracouta Thyrsites atun, $\mathrm{n}=36$; JM: jack mackerel Trachurus declivis, $\mathrm{n}=52$; $\mathrm{RC}$ : red cod Pseudophysis bachus, n = 9; LJ: leatherjackets (family Monocanthidae), $\mathrm{n}=10 ;$ GS: Gould's squid Nototodarus gouldi, $\mathrm{n}=8$; RB: redbait Emmelichthys nitidus, $\mathrm{n}=25$; MG: minor gurnard Lepidotrigla modesta, $\mathrm{n}=29$; CF: cuttlefish Sepia sp., n = 5; MO: Maori octopus Octopus maorum, n = 4; KO: keeled octopus Octopus berrima, $\mathrm{n}=1$

Table 2. Arctocephalus pusillus doriferus. Characteristics of the adult female Australian fur seals on Kanowna Island from which plasma samples were obtained for stable isotope analysis from 2003 to 2005 . Not all variables could be measured in each individual

\begin{tabular}{|lcrrr|}
\hline Variable & $\mathrm{n}$ & Mean $\pm \mathrm{SE}$ & Min. & Max. \\
\hline Age & 120 & $8.7 \pm 0.3$ & 3 & 16 \\
Mass $(\mathrm{kg})$ & 121 & $81.0 \pm 1.1$ & 50 & 112 \\
Standard length $(\mathrm{cm})$ & 120 & $154.5 \pm 0.8$ & 134 & 175 \\
Axillary girth $(\mathrm{cm})$ & 120 & $103.7 \pm 0.8$ & 82 & 132 \\
Flipper length $(\mathrm{cm})$ & 108 & $42.7 \pm 0.2$ & 39 & 49 \\
\hline
\end{tabular}

The range of $\delta^{13} \mathrm{C}$ and $\delta^{15} \mathrm{~N}$ values in the Kanowna Island samples from 1998 to 2000 (2.1 and $2.2 \%$, respectively) was similar to that observed in the 2003 to 2005 samples (2.7 and 2.5\%, respectively), suggesting that individuals within both sampling periods experienced a similar variety of foraging conditions and prey diversities. Within the range observed in the latter sampling period, there was a significant negative correlation between $\delta^{15} \mathrm{~N}$ and female age (weighted leastsquares regression: $F_{1,12}=8.14, \mathrm{r}^{2}=$ 0.40, p $<0.01$; Fig. 3). No significant relationship was evident for $\delta^{13} \mathrm{C}$ values.

Six generalized linear models examining the relationships between $\delta^{13} \mathrm{C}$ and individual characteristics were produced and had substantial support (Table 3). All the supported models included the ratio FL/STDL, indicating some importance of this variable. The $\mathrm{R}^{2}$ values for all the models were very low, indicating there is considerable variation unaccounted for by these models, and, thus, any interpretation of these data must be treated with caution. Model averaging was conducted due to the lack of a single best model for the candidate set of models. High summed AIC weights and high independent hierarchical partitioning contributions suggest that the ratio FL/STDL had a positive influence on $\delta^{13} \mathrm{C}$ values (Table 4 ). Age of the seal, with moderate summed AIC weights and $15.2 \%$ independent contributions, may also have a positive influence on the $\delta^{13} \mathrm{C}$ levels of seals (Table 4 ).

The generalized linear models investigating individual influences on $\delta^{15} \mathrm{~N}$ isotope values that had substantial support all included BM and FL, indicating their broad importance

Small, but significant differences, however, were observed in both isotopes between lactating and non-lactating individuals. Plasma $\delta^{13} \mathrm{C}$ was more enriched by $0.3 \%$ in lactating females $\left(-18.4 \pm 0.1 \%\right.$, $t_{30.94}=-2.56$, $\mathrm{p}<0.05)$, while, conversely, $\delta^{15} \mathrm{~N}$ in non-lactating females $(14.3 \pm 0.1 \%$ o was enriched by $0.4 \%$ in comparison to non-lactating individuals $\left(t_{108}=2.47, \mathrm{p}<0.05\right)$. In contrast to the inter-annual comparisons, $\delta^{15} \mathrm{~N}$ was not significantly correlated with individual BCI ( $p>0.3)$.
(Table 3 ). The $\mathrm{R}^{2}$ values for all the models were relatively low, indicating there is considerable variation unaccounted for by these models. Model averaging was conducted, as no single model had substantial support for being the best candidate model. The bootstrap weights from model averaging suggest that the top 2 models are likely the best from this candidate set of models (Table 3). High summed AIC weights and high independent hierarchical partitioning contribu- 

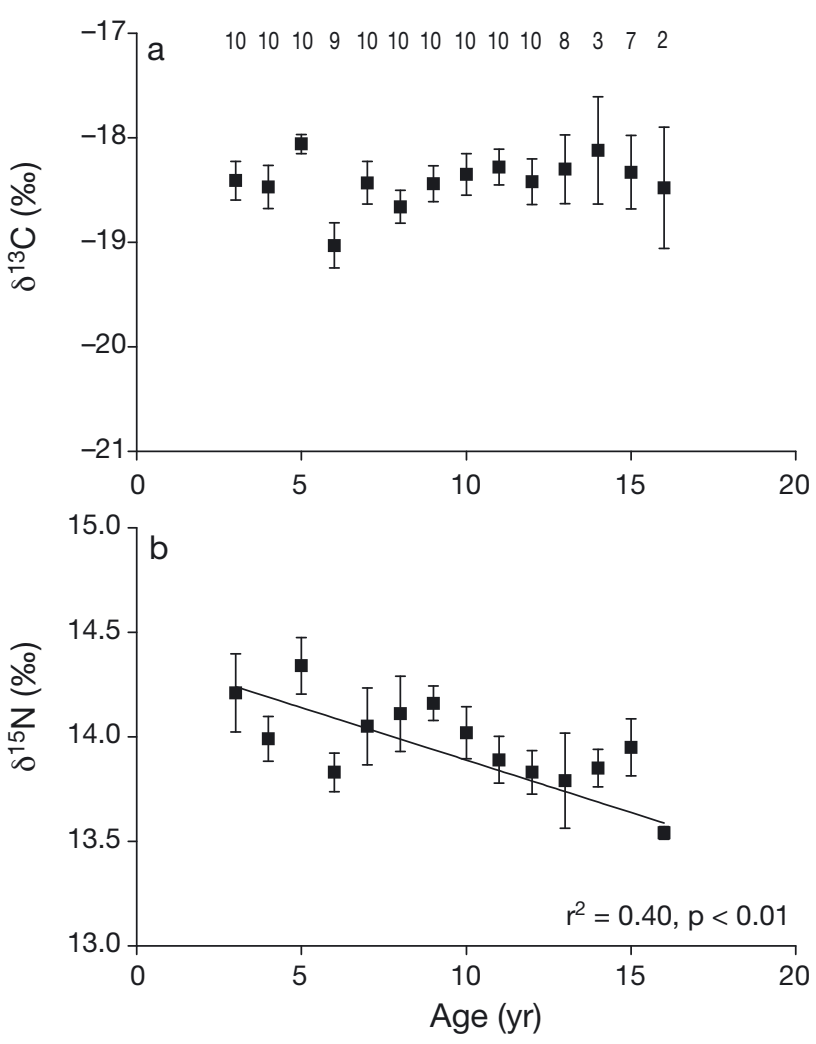

Fig. 3. Arctocephalus pusillus doriferus. Relationship between age and mean ( ${ } \mathrm{SE}$ ) plasma (a) $\delta^{13} \mathrm{C}$ and (b) $\delta^{15} \mathrm{~N}$ in adult female Australian fur seals from Kanowna Island (2003 to 2005). Sample sizes for each cohort are given above the data

tions suggest that BM had a negative influence on plasma $\delta^{15} \mathrm{~N}$ (Table 4). FL also had high summed AIC weights, but lower independent hierarchical partitioning contributions (Table 4). While the contribution of FL was not as strong, it appears that FL had a positive influence on plasma $\delta^{15} \mathrm{~N}$. Therefore, although the amount of variation accounted for by these models is relatively low, it appears plasma $\delta^{15} \mathrm{~N}$ was influenced to some extent by the BM of individuals, as well as by their FL.

\section{DISCUSSION}

\section{Trophic implications of isotopic values}

The only previous data available on stable isotopes in Australian fur seals is for 2 individuals (sex and location not documented), in which the $\delta^{15} \mathrm{~N}$ value in muscle was 15.8\% (Davenport \& Bax 2002). In comparison to blood, muscle has been shown in pinnipeds to differ in $\delta^{15} \mathrm{~N}$ by $+0.7 \%$ o (Hobson et al. 1996). Consequently, the $\delta^{15} \mathrm{~N}$ values in the present study encompass those previously reported for Australian fur seals and are consistent with the observation by Davenport \& Bax (2002) that the species occupies the highest trophic level within the Bass Strait marine ecosystem.

Because of differences in metabolism and protein turnover, the isotopic signatures of different tissues can provide information on diet at various timescales, with plasma, red cells and liver reflecting shorter integrating periods than muscle, hair and bone (Tieszen et al. 1983, Hobson et al. 1996). Isotopic turnover rates have not been established for any tissues in Australian fur seals, nor are there data for blood components in pinnipeds. Hilderbrand et al. (1996), however, determined that plasma and red cells in a large eutherian mammal (black bear Ursus americanus) had half-lives of 4 and $28 \mathrm{~d}$, respectively, and that it took approximately 10 and $>40 \mathrm{~d}$ for isotope values in these blood compo-

Table 3. Arctocephalus pusillus doriferus. $\mathrm{AIC}_{\mathrm{C}}$ based model selection for the levels of $\delta^{13} \mathrm{C}$ and $\delta^{15} \mathrm{~N}$ in the blood of seals. Values represent the number of parameters $(K)$, Akaike information criterion corrected for small sample sizes (AIC $)_{C}$, AIC differences $(\triangle \mathrm{AIC})$, Akaike weights $\left(\omega_{i}\right)$, bootstrap selection frequencies $(i)$ and regression explanation scores $\left(\mathrm{R}^{2}\right)$ for the best models and evidence ratios $\left(\omega_{i} / \omega_{j}\right)$. The best 4 models are provided. Extra models are provided if $>4$ models had a $\Delta$ AIC score of $<2$. Model variables: Age (yr); STDL: standard length $(\mathrm{cm})$; BM: body mass $(\mathrm{kg})$; FL: flipper length (cm); ratio FL/STDL

\begin{tabular}{|c|c|c|c|c|c|c|c|c|}
\hline Model & $K$ & $\mathrm{AIC}_{\mathrm{c}}$ & $\Delta \mathrm{AIC}$ & Rank & $\omega_{i}$ & $i$ & $\mathrm{R}^{2}$ & $\omega_{i} / \omega_{j}$ \\
\hline \multicolumn{9}{|l|}{$\delta^{13} \mathbf{C}$} \\
\hline Age + FL/STDL & 4 & 216 & 0.000 & 1 & 0.155 & 0.276 & 0.090 & - \\
\hline $\mathrm{BM}+\mathrm{FL} / \mathrm{STDL}$ & 4 & 217 & 0.957 & 2 & 0.096 & 0.097 & 0.082 & 1.61 \\
\hline FL/STDL & 3 & 217 & 1.009 & 3 & 0.094 & 0.168 & 0.063 & 1.66 \\
\hline Age + FL + FL/STDL & 5 & 218 & 1.855 & 4 & 0.061 & 0.028 & 0.093 & 2.53 \\
\hline Age + BM + FL/STDL & 5 & 218 & 1.954 & 5 & 0.058 & 0.009 & 0.092 & 2.66 \\
\hline Age + STDL + FL/STDL & 5 & 218 & 1.969 & 6 & 0.058 & 0.009 & 0.092 & 2.68 \\
\hline \multicolumn{9}{|l|}{$\delta^{15} \mathbf{N}$} \\
\hline $\mathrm{BM}+\mathrm{FL}$ & 4 & 112.9 & 0.000 & 1 & 0.226 & 0.337 & 0.148 & - \\
\hline $\mathrm{STDL}+\mathrm{BM}+\mathrm{FL}+\mathrm{FL} / \mathrm{STDL}$ & 6 & 114.1 & 1.172 & 2 & 0.1259 & 0.291 & 0.173 & 1.80 \\
\hline STDL + BM + FL & 5 & 114.7 & 1.725 & 3 & 0.0955 & 0.016 & 0.152 & 2.37 \\
\hline Age + BM + FL & 5 & 115.0 & 2.095 & 4 & 0.079 & 0.038 & 0.149 & 2.85 \\
\hline
\end{tabular}


Table 4. Arctocephalus pusillus doriferus. Model averaged coefficients, conditional and unconditional standard errors, Z-scores and significance of each variable in each model (Pr), and summed Akaike information criterion (AIC) weights (total AIC weight for each model including that variable). Results from hierarchical partitioning are shown, with the percentage of independent contributions. Variables as in Table 3

\begin{tabular}{|c|c|c|c|c|c|c|c|}
\hline \multirow{2}{*}{ Variable } & \multirow{2}{*}{ Coefficient } & \multicolumn{2}{|c|}{$\longrightarrow$ Standard error } & \multirow{2}{*}{$Z$} & \multirow{2}{*}{$\operatorname{Pr}(>|Z|)$} & \multirow{2}{*}{ Contribution } & \multirow{2}{*}{$\begin{array}{c}\text { Summed } \\
\text { AIC weights }\end{array}$} \\
\hline & & Conditional & Unconditional & & & & \\
\hline \multicolumn{8}{|l|}{$\delta^{13} \mathbf{C}$} \\
\hline Age & 0.016 & 0.0235 & 0.019 & 0.878 & 0.380 & 15.2 & 0.529 \\
\hline STDL & -0.003 & 0.041 & 0.016 & -0.167 & 0.867 & 14.8 & 0.378 \\
\hline $\mathrm{BM}$ & 0.005 & 0.010 & 0.007 & 0.631 & 0.528 & 9.9 & 0.416 \\
\hline FL & -0.008 & 0.144 & 0.057 & -0.142 & 0.887 & 16.7 & 0.385 \\
\hline FL/STDL & 13.246 & 21.979 & 8.504 & 1.558 & 0.119 & 43.4 & 0.831 \\
\hline \multicolumn{8}{|l|}{$\delta^{15} \mathbf{N}$} \\
\hline Age & -0.001 & 0.014 & 0.006 & -0.117 & 0.907 & 6.9 & 0.263 \\
\hline STDL & -0.020 & 0.025 & 0.024 & -0.841 & 0.400 & 19.3 & 0.432 \\
\hline $\mathrm{BM}$ & -0.012 & 0.006 & 0.005 & -2.388 & 0.017 & 34.3 & 0.881 \\
\hline FL & 0.102 & 0.088 & 0.088 & 1.155 & 0.248 & 16.7 & 0.774 \\
\hline FL/STDL & -8.574 & 13.514 & 12.719 & -0.674 & 0.500 & 22.8 & 0.474 \\
\hline
\end{tabular}

nents, respectively, to reflect changes to an isotopically distinct diet. The mean foraging cycle (trip and attendance) duration of adult female Australian fur seals at The Skerries has been recorded as $8.7 \mathrm{~d}$ (Arnould \& Kirkwood 2007). Consequently, assuming similar isotope turnover rates in Australian fur seals to that reported for black bears, the significant correlations between isotope values in plasma and red blood cells observed in animals from The Skerries suggest that isotopic inputs and, thus, prey species, were relatively consistent within individuals over at least the 3 or 4 foraging trips prior to sampling. Significant correlations between red cell and plasma isotope values, suggesting consistent individual preferences in diet over several months, have also been observed in South American sea lions Otaria flavescens (Drago et al. 2010).

Australian fur seals have been shown to consume a wide variety of prey, and the species is considered to be a generalist predator (Littnan et al. 2007, Kirkwood et al. 2008). If the individual consistency in isotope values observed at The Skerries is representative of the species in general, the substantial variation observed within years and at each site suggests that female Australian fur seals display distinct individual dietary preferences. While the species is primarily a benthic forager on the relatively uniform shallow continental shelf of Bass Strait (Arnould \& Hindell 2001, Arnould \& Kirkwood 2007), recent tracking studies have shown that females target prey in individually preferred areas (Arnould et al. unpubl. data). It is possible that these areas correspond to differences in the availability of various prey types and, therefore, that the Australian fur seal population is comprised of an array of specialist foragers. Similar instances of individual specialisation in foraging areas and diet have been observed in another benthic forager, the Australian sea lion Neophoca cinerea (Baylis et al. 2009).

In the present study, mean $\delta^{15} \mathrm{~N}$ values in each year of sampling ranged from 13.8 to $16.4 \%$. Isotope fractionation values are not available for Australian fur seals, but prey-to-tissue fractionation values of from 3.1 to $5.2 \%$ have been reported for serum/plasma $\delta^{15} \mathrm{~N}$ in captive pinnipeds (Kurle 2002). These would equate to mean prey $\delta^{15} \mathrm{~N}$ values of from 10.7 to $13.2 \%$ and from 8.6 to $11.2 \%$, respectively. Isotope data on potential prey were not collected in the present study, but, where possible, data for the fish and cephalopod species consistently identified as being the most important in faecal analyses (Gales et al. 1993, Gales \& Pemberton 1994, Hume et al. 2004, Page et al. 2005, Littnan et al. 2007, Kirkwood et al. 2008) were obtained from a previous ecosystem study in eastern Bass Strait (Davenport \& Bax 2002; Fig. 2, present study), a region encompassing The Skerries. While not exhaustive, this list is likely to represent the greatest biomass contributions to the diet. With the exception of keeled octopus Octopus berrima, the $\delta^{15} \mathrm{~N}$ values for these prey were all within 11.5 to $13.3 \%$, thus suggesting that a $3.1 \%$ prey-to-tissue fractionation for plasma appears appropriate for Australian fur seals.

Previous studies have documented geographic differences in the diet of Australian fur seals, though these may have been partially due to temporal variations, as samples were collected over different time periods (Gales et al. 1993, Hume et al. 2004, Deagle et al. 2009). Littnan et al. (2007) compared the diet of Australian fur seals at both Kanowna Island and The Skerries during the same period that blood samples were collected for the present study. Whereas Littnan et al. (2007) did not find significant differences in the 
prey remains in faeces and regurgitates between the 2 sites, significant differences in $\delta^{15} \mathrm{~N}$ values were detected in the present study, suggesting stable isotope analyses, as has also been recently suggested for faecal DNA analysis (Deagle et al. 2009), may provide a more sensitive means of detecting inter-colony differences than traditional methods. The benefit of stable isotope analysis over faecal DNA methods, however, may be the multiple time-scales that various tissues provide and the relatively simple sample processing and analyses required (Tieszen et al. 1983, Hobson et al. 1996, Deagle et al. 2009).

Whereas $\delta^{15} \mathrm{~N}$ values are indicative of trophic position, $\delta^{13} \mathrm{C}$ values can been used to infer the geographic origin of prey as the isotope signature of particulate organic matter (POM), and the trophic levels above it, vary with location (e.g. Trull \& Armand 2001, Cherel et al. 2007). Prey-to-tissue fractionation for serum/plasma $\delta^{13} \mathrm{C}$ in pinnipeds has been reported to be between 0.2 and $0.8 \%$ (Kurle 2002, Lesage et al. 2002). For the individuals in the present study, therefore, this would equate to prey with $\delta^{13} \mathrm{C}$ values in the range of from -18.4 to $-20.5 \%$. The majority of $\delta^{13} \mathrm{C}$ values reported by Davenport \& Bax (2002) for commonly consumed prey, however, are higher than this (Fig. 2). As Australian fur seals forage almost exclusively within Bass Strait (Arnould \& Hindell 2001, Arnould \& Kirkwood 2007), the results suggest that some of their prey originate from outside the region. In addition, while the Davenport \& Bax (2002) study encompassed the area in which animals from The Skerries forage (Arnould \& Kirkwood 2007), it was conducted in 1993 to 1996 and the region may have been under different oceanographic influences at the time.

The shallow continental shelf of Bass Strait has been characterised as having low marine primary productivity, but it is fed by the currents of the Subantarctic Surface Water (SASW) from the south, the South Australian Current (SAC) from the northwest and the East Australia Current (EAC) from the northeast (Gibbs 1991, Middleton \& Bye 2007). The strengths of these currents, each of which is likely to have different POM isotope signatures (Waite et al. 2007, Revill et al. 2009), vary temporally, but most flow through Bass Strait is in an eastward direction and is influenced by the predominantly westerly winds across southern Australia (Middleton \& Bye 2007). In addition, some prey, such as redbait, which originate from deeper outer-shelf waters and move to shallower depths when surface waters cool, may be carried into Bass Strait by these currents (Williams \& Pullen 1993, Ewing \& Lyle 2009). These factors may have contributed to the variability in, and apparently low, $\delta^{13} \mathrm{C}$ values observed in the present study. Further information on the spatial variability in the isotopic signatures of prey species, especially in western and central Bass Strait, is needed to better assess the geographic origin of the Australian fur seal diet.

\section{Inter-annual and inter-individual variation}

For a generalist predator known to consume $>60$ prey species (Kirkwood et al. 2008, Deagle et al. 2009), detecting temporal or spatial differences in diet may be problematic if diet changes involve only mild alterations in the relative proportions in a suite of prey. For isotope analyses, this would be further compounded if the prey involved were on similar trophic levels. In the present study, however, significant differences in plasma $\delta^{15} \mathrm{~N}$ values were observed between the 1998 to 2000 and 2003 to 2005 sampling periods, corresponding to two-thirds (ca. $2 \%$ ) of a trophic level (Minagawa \& Wada 1984). While it is possible that some of this variation could be due to changes in ocean currents bringing the same prey species from different isotopic environments into Bass Strait, these results are consistent with the findings of Kirkwood et al. (2008), which indicated a shift in the diet of Australian fur seals in central Bass Strait between the 2 periods. Coinciding with cooler surface waters in Bass Strait in 2002 to 2005 , the proportion of redbait $\left(11.6 \%\right.$ o $\left.\delta^{15} \mathrm{~N}\right)$ in the diet increased, while red cod and barracouta (both $13.3 \% \delta^{15} \mathrm{~N}$ ) decreased. In addition, Kirkwood et al. (2008) observed a significant decrease in the size of Gould's squid $\left(12.9 \% \delta^{15} \mathrm{~N}\right)$ consumed by seals after 2002. A reduction in the biomass consumption of this prey, therefore, would reduce the $\delta^{15} \mathrm{~N}$ values in seals.

The period of higher $\delta^{15} \mathrm{~N}$ values coincided with adult females having greater mean BCI values. This would suggest that foraging conditions were more favourable when the seals consumed relatively more red cod, barracouta and jack mackerel and larger Gould's squid than when redbait predominated in the diet (Kirkwood et al. 2008). This is surprising as redbait have a lipid content 2- to 3-fold higher than the other commonly consumed prey (Vlieg 1984). However, while redbait were recorded as forming a larger proportion of the Australian fur seal diet from 2002 to 2005, it is not known whether this species was in relatively greater abundance than usual in comparison to other prey and/or whether total prey availability was different. In addition, due to their manoeuvrability, small schooling fish such as redbait may be harder for Australian fur seals to capture than larger prey such as Gould's squid and barracouta (Fish et al. 2003); thus, even at higher abundance, they may be less profitable (Arnould \& Costa 2006).

Small but significant differences in plasma isotope values were observed between lactating and nonlactating females, the latter being depleted in $\delta^{13} \mathrm{C}$ and enriched in $\delta^{15} \mathrm{~N}$. While these isotope values could 
indicate differences in dietary intake between the 2 groups, similar observations for $\delta^{15} \mathrm{~N}$ have been made in a captive northern fur seal fed a consistent diet during lactating and non-lactating periods (Kurle 2002). Alternatively, the differences may reflect variations in the physiology of the animals, including the metabolism of specific amino acids between the 2 reproductive states (Houser \& Crocker 2004).

No significant age-related trends in plasma $\delta^{13} \mathrm{C}$ values were observed in the 2003 to 2005 sampling period, suggesting adult female Australian fur seals of all ages consume prey of generally the same geographic origin. This is consistent with tracking data that indicate the foraging range of adult females from Kanowna Island is largely restricted to the central Bass Strait region (Arnould \& Kirkwood 2007). In contrast, a significant decrease in mean $\delta^{15} \mathrm{~N}$ values was observed over the 14 yr age-span covered. While the observed decrease represents an average decline of just $0.7 \%$ over most of the adult life-span, considering the large array of prey consumed by this species, it suggests a consistent shift in the proportions of prey consumed from different trophic levels with age. Due to differences in the contributions of various age cohorts to the population (e.g. ages 3 to 9 yr represent $>70 \%$ of adult females (Gibbens \& Arnould 2009a), such age-related changes may have important implications for estimates of a population's prey consumption (Winship et al. 2002).

Whereas numerous studies have shown age-related differences in the diet and foraging behaviour of pinnipeds, these have been restricted to the differences between juveniles and adults (e.g. Tucker et al. 2007). Few studies have documented age-related differences in the trophic niches of adult pinnipeds. While no significant differences in $\delta^{15} \mathrm{~N}$ values were observed with age in southern sea lions, Drago et al. (2009a) observed an increase in $\delta^{13} \mathrm{C}$ suggestive of a shift to more benthic prey species in older animals. Hanson et al. (2009) observed a linear increase in $\delta^{15} \mathrm{~N}$ values in the teeth of male Antarctic fur seals up to age 7. While Antarctic fur seals are sexually mature at an age of 3 to $4 \mathrm{yr}$, they continue to grow and generally do not hold territories until they are 7 to 8 yr old (Payne 2010). Consequently, male Antarctic fur seals appear to consume increasing amounts of prey from higher trophic levels (krill-eating and piscivorous fish) during the post-pubertal stage of rapid growth (Hanson et al. 2009). In contrast, the decrease in $\delta^{15} \mathrm{~N}$ observed in the present study indicates adult female Australian fur seals consume increasing amounts of lower trophic level prey with age. Potential prey that could account for this are octopus species. Indeed, recent studies involving animalborne video cameras suggest that octopus (Arnould et al. unpubl. data), in particular the keeled octopus, are regularly consumed and may account for a greater pro- portion of the diet than previously assumed, because their beaks rarely appear in faeces (Gales \& Cheal 1992, Gales et al. 1993). Whether older Australian fur seal females consume greater amounts of octopus, or other, as yet undetermined, prey of lower trophic levels, than younger seals remains to be determined.

In addition to the observed decrease in $\delta^{15} \mathrm{~N}$ with age, there was substantial inter-individual variation (range: ca. $2 \%$ ) within each age cohort. Such variation suggests that individual specialisation for particular prey types is evident early in adulthood, but that its composition changes as females age. This is consistent with the findings of generalized linear models that body mass has a negative influence on $\delta^{15} \mathrm{~N}$. Body mass has been found to be a significant determinant of foraging behaviour in pinnipeds (Weise et al. 2010), as greater mass equates to larger total body oxygen stores, which facilitate longer submergence times (Villegas-Amtmann et al. 2008). This may be particularly important for individuals that hunt cryptic prey on the sea floor (e.g. octopus, gurnards) or prey that require greater encounter-to-capture time. The range of trophic niches displayed by individuals within each age cohort, therefore, may reflect foraging choices mediated by body size, which continues to increase slightly throughout adulthood (Arnould \& Warneke 2002). Clearly, individual specialisation (and its potential consequences on fitness) in Australian fur seals requires further investigation; this can be achieved by examining the isotopic signatures of archival tissues that record foraging over the long-term (e.g. whiskers; Cherel et al. 2009).

In summary, the present study has demonstrated that $\mathrm{C}$ and $\mathrm{N}$ isotopic analyses of blood samples can detect population-wide, inter-annual variations in the diet of the Australian fur seal, a generalist predator. Consequently, the technique could be used as a potentially cost-effective monitoring tool, especially if samples were to be collected from different age/sex classes. In addition, the study revealed substantial interindividual differences in trophic position, suggesting that adult females display individual prey preferences from an early stage on, and that these are potentially mediated by body size limitations/advantages and may change with age. To better understand these relationships, further studies investigating the species composition of the diet of different aged individuals and showing how this relates to individual characteristics and foraging behaviours are needed.

\section{LITERATURE CITED}

Anderson DR, Link WA, Johnson DH, Burnham KP (2001) Suggestions for presenting the results of data analyses. J Wildl Manag 65:373-378 
Arim M, Naya DE (2003) Pinniped diets inferred from scats: analysis of biases in prey occurrence. Can J Zool 81:67-73

Arnbom TA, Lunn NJ, Boyd IL, Barton T (1992) Aging live Antarctic fur seals and southern elephant seals. Mar Mamm Sci 8:37-43

Arnould JPY, Costa DP (2006) Sea lions in drag, fur seals incognito: insights from the otariid deviants. In: Trites AW Atkinson SK, DeMaster DP, Fritz LW, Gelatt TS, Rea LD, Wynne KM (eds) Sea lions of the world: conservation and research in the 21st century. Proceedings of the 22nd Wakefield Fisheries Symposium. Alaska Sea Grant College Program, Anchorage, AK

Arnould JPY, Hindell MA (2001) Dive behaviour, foraging locations, and maternal-attendance patterns of Australian fur seals (Arctocephalus pusillus doriferus). Can J Zool 79: $35-48$

Arnould JPY, Kirkwood R (2007) Habitat selection by female Australian fur seals (Arctocephalus pusillus doriferus). Aquat Conserv 17:S53-S67

Arnould JPY, Warneke RM (2002) Growth and condition in Australian fur seals (Arctocephalus pusillus doriferus) (Carnivora: Pinnipedia). Aust J Zool 50:53-66

- Arnould JPY, Morris MJ, Rawlins DR, Boyd IL (2002) Variation in plasma leptin levels in response to fasting in Antarctic fur seals (Arctocephalus gazella). J Comp Physiol B 172:27-34

Baylis AMM, Hamer DJ, Nichols PD (2009) Assessing the use of milk fatty acids to infer the diet of the Australian sea lion (Neophoca cinerea). Wildl Res 36:169-176

Bertram DF, Mackas DL, McKinnell SM (2001) The seasonal cycle revisited: interannual variation and ecosystem consequences. Prog Oceanogr 49:283-307

Boyd IL, Murray AWA (2001) Monitoring a marine ecosystem using responses of upper trophic level predators. J Anim Ecol 70:747-760

Burnham KP, Anderson DR (2002) Model selection and multi-model inference: a practical information-theoretic approach. Springer-Verlag, New York, NY

Cheneval O, Blake RW, Trites AW, Chan KHS (2007) Turning maneuvers in Steller sea lions (Eumatopias jubatus). Mar Mamm Sci 23:94-109

Cherel Y, Hobson KA, Weimerskirch H (2005) Using stable isotopes to study resource acquisition and allocation in procellariiform seabirds. Oecologia 145:533-540

> Cherel Y, Hobson KA, Guinet C, Vanpe C (2007) Stable isotopes document seasonal changes in trophic niches and winter foraging individual specialization in diving predators from the Southern Ocean. J Anim Ecol 76:826-836

Cherel Y, Kernaleguen L, Richard P, Guinet C (2009) Whisker isotopic signature depicts migration patterns and multiyear intra- and inter-individual foraging strategies in fur seals. Biol Lett 5:830-832

$>$ Davenport SR, Bax NJ (2002) A trophic study of a marine ecosystem off southeastern Australia using stable isotopes of carbon and nitrogen. Can J Fish Aquat Sci 59:514-530

> Deagle BE, Kirkwood R, Jarman SN (2009) Analysis of Australian fur seal diet by pyrosequencing prey DNA in faeces. Mol Ecol 18:2022-2038

Dellinger T, Trillmich F (1988) Estimating diet composition from scat analysis in otariid seals (Otariidae): Is it reliable? Can J Zool 66:1865-1870

- Deniro MJ, Epstein S (1977) Mechanism of carbon isotope fractionation associated with lipid synthesis. Science 197:261-263

> Drago M, Cardona L, Crespo EA, Aguilar A (2009a) Ontogenic dietary changes in South American sea lions. J Zool 279:251-261
Drago M, Crespo EA, Aguilar A, Cardona L, Garcia N, Dans SL, Goodall N (2009b) Historic diet change of the South American sea lion in Patagonia as revealed by isotopic analysis. Mar Ecol Prog Ser 384:273-286

- Drago M, Cardona L, Aguilar A, Crespo EA, Ameghino S, Garcia N (2010) Diet of lactating South American sea lions, as inferred from stable isotopes, influences pup growth. Mar Mamm Sci 26:309-323

Ewing GP, Lyle JM (2009) Reproductive dynamics of redbait, Emmelichthys nitidus (Emmelichthyidae), from southeastern Australia. Fish Res 97:206-215

- Fish FE, Hurley J, Costa DP (2003) Manoeuvrability by the sea lion Zalophus californianus: turning performance of an unstable body design. J Exp Biol 206:667-674

Fulton EA, Smith ADM, Johnson CR (2004) Effects of spatial resolution on the performance and interpretation of marine ecosystem models. Ecol Model 176:27-42

Gales NJ, Cheal AJ (1992) Estimating diet composition of the Australian sea lion (Neophoca cinerea) from scat analysis: an unreliable technique. Wildl Res 19:447-456

Gales NJ, Mattlin RH (1998) Fast, safe, field-portable gas anesthesia for otariids. Mar Mamm Sci 14:355-361

Gales R, Pemberton D (1994) Diet of the Australian fur seal in Tasmania. Aust J Mar Freshw Res 45:653-664

> Gales R, Pemberton D, Lu CC, Clarke MR (1993) Cephalopod diet of the Australian fur seal: variation due to location, season and sample type. Aust J Mar Freshw Res 44: $657-671$

> Gibbens J, Arnould JPY (2009a) Age-specific growth, survival, and population dynamics of female Australian fur seals. Can J Zool 87:902-911

Gibbens J, Arnould JPY (2009b) Interannual variation in pup production and the timing of breeding in benthic foraging Australian fur seals. Mar Mamm Sci 25:573-587

Gibbens J, Parry LJ, Arnould JPY (2010) Influences on fecundity in Australian fur seals (Arctocephalus pusillus doriferus). J Mammal 91:510-518

- Gibbs CF (1991) Oceanography of Bass Strait: implications for the food supply of little penguins Eudyptula minor. Emu 91:395-401

Goldsworthy SD, Bulman C, He X, Larcombe J, Littnan CL (2003) Trophic interactions between marine mammals and Australian fisheries: an ecosystem approach. In: Gales NJ, Hindell MA, Kirkwood R (eds) Marine mammals: fisheries, tourism, and management issues. CSIRO Publishing, Melbourne

- Hall-Aspland SA, Hall AP, Rogers TL (2005a) A new approach to the solution of the linear mixing model for a single isotope: application to the case of an opportunistic predator. Oecologia 143:143-147

Hall-Aspland SA, Rogers TL, Canfield RB (2005b) Stable carbon and nitrogen isotope analysis reveals seasonal variation in the diet of leopard seals. Mar Ecol Prog Ser 305: $249-259$

> Hammill MO, Lesage V, Carter P (2005) What do harp seals eat? Comparing diet composition from different compartments of the digestive tract with diets estimated from stable-isotope ratios. Can J Zool 83:1365-1372

- Hanson NN, Wurster CM, Bird MI, Reid K, Boyd IL (2009) Intrinsic and extrinsic forcing in life histories: patterns of growth and stable isotopes in male Antarctic fur seal teeth. Mar Ecol Prog Ser 388:263-272

Hilderbrand GV, Farley SD, Robbins CT, Hanley TA, Titus K, Servheen C (1996) Use of stable isotopes to determine diets of living and extinct bears. Can J Zool 74:2080-2088

> Hobson KA, Schell DM, Renouf D, Noseworthy E (1996) Stable carbon and nitrogen isotopic fractionation between 
diet and tissues of captive seals: implications for dietary reconstructions involving marine mammals. Can J Fish Aquat Sci 53:528-533

Houser DS, Crocker DE (2004) Age, sex, and reproductive state influence free amino acid concentrations in the fasting elephant seal. Physiol Biochem Zool 77:838-846

$>$ Huckstadt LA, Rojas CP, Antezana T (2007) Stable isotope analysis reveals pelagic foraging by the southern sea lion in central Chile. J Exp Mar Biol Ecol 347:123-133

Hume F, Hindell MA, Pemberton D, Gales R (2004) Spatial and temporal variation in the diet of a high trophic level predator, the Australian fur seal (Arctocephalus pusillus doriferus). Mar Biol 144:407-415

> Ihaka R, Gentleman R (1996) R: a language for data analysis and graphics. J Comput Graph Statist 5:299-314

Kirkwood R, Gales R, Terauds A, Arnould JPY and others (2005) Pup production and population trends of the Australian fur seal (Arctocephalus pusillus doriferus). Mar Mamm Sci 21:260-282

Kirkwood R, Hume F, Hindell M (2008) Sea temperature variations mediate annual changes in the diet of Australian fur seals in Bass Strait. Mar Ecol Prog Ser 369:297-309

Kirkwood RJ, Pemberton D, Gales R, Hoskins AJ, Mitchell T, Shaughnessy PD, Arnould JPY (2010) Continued population recovery by Australian fur seals. Mar Freshw Res 61:695-701

Kurle CM (2002) Stable-isotope ratios of blood components from captive northern fur seals (Callorhinus ursinus) and their diet: applications for studying the foraging ecology of wild otariids. Can J Zool 80:902-909

Lea MA, Guinet C, Cherel Y, Duhamel G, Dubroca L, Pruvost P, Hindell M (2006) Impacts of climatic anomalies on provisioning strategies of a Southern Ocean predator. Mar Ecol Prog Ser 310:77-94

Lesage V, Hammill MO, Kovacs KM (2002) Diet-tissue fractionation of stable carbon and nitrogen isotopes in phocid seals. Mar Mamm Sci 18:182-193

Littnan CL (2003) Approaches to studying the foraging ecology of the Australian fur seal Arctocephalus pusillus doriferus in northern Bass Strait. PhD thesis, Macquarie University, Sydney

Littnan CL, Arnould JPY, Harcourt RG (2007) Effect of proximity to the shelf edge on the diet of female Australian fur seals. Mar Ecol Prog Ser 338:257-267

Middleton JF, Bye JAT (2007) A review of the shelf-slope circulation along Australia's southern shelves: Cape Leeuwin to Portland. Prog Oceanogr 75:1-41

Minagawa M, Wada E (1984) Stepwise enrichment of ${ }^{15} \mathrm{~N}$ along food-chains: further evidence and the relation between $\delta^{15} \mathrm{~N}$ and animal age. Geochim Cosmochim Acta 48:1135-1140

Misarti N, Finney B, Maschner H, Wooller MJ (2009) Changes in northeast Pacific marine ecosystems over the last 4500 years: evidence from stable isotope analysis of bone collagen from archeological middens. Holocene 19: 1139-1151

> Newsome SD, Tinker MT, Monson DH, Oftedal OT and others (2009) Using stable isotopes to investigate individual diet specialization in California sea otters (Enhydra lutris nereis). Ecology 90:961-974

Page B, McKenzie J, Goldsworthy SD (2005) Dietary resource partitioning among sympatric New Zealand and Aus-

Editorial responsibility: Michael Castellini,

Fairbanks, Alaska, USA tralian fur seals. Mar Ecol Prog Ser 293:283-302

Payne MR (2010) Growth in the Antarctic fur seal Arctocephalus gazella. J Zool 187:1-20

> Porras-Peters H, Aurioles-Gamboa D, Cruz-Escalona VH, Koch PL (2008) Trophic level and overlap of sea lions (Zalophus californianus) in the Gulf of California, Mexico. Mar Mamm Sci 24:554-576

Reid K, Barlow KE, Croxall JP, Taylor RI (1999) Predicting changes in the Antarctic krill, Euphausia superba, population at South Georgia. Mar Biol 135:647-652

Reid K, Croxall JP, Briggs DR, Murphy EJ (2005) Antarctic ecosystem monitoring: quantifying the response of ecosystem indicators to variability in Antarctic krill. ICES J Mar Sci 62:366-373

> Revill AT, Young JW, Lansdell M (2009) Stable isotopic evidence for trophic groupings and bio-regionalization of predators and their prey in oceanic waters off eastern Australia. Mar Biol 156:1241-1253

Rolland V, Barbraud C, Weimerskirch H (2009) Assessing the impact of fisheries, climate and disease on the dynamics of the Indian yellow-nosed albatross. Biol Conserv 142: $1084-1095$

Smedes F (1999) Determination of total lipid using nonchlorinated solvents. Analyst (Lond) 124:1711-1718

> Tieszen LL, Boutton TW, Tesdahl KG, Slade NA (1983) Fractionation and turnover of stable carbon isotopes in animal tissues: implications for $\delta^{13} \mathrm{C}$ analysis of diet. Oecologia 57:32-37

> Trull TW, Armand L (2001) Insights into Southern Ocean carbon export from the $\delta^{13} \mathrm{C}$ of particles and dissolved inorganic carbon during the SOIREE iron release experiment. Deep-Sea Res II 48:2655-2680

Tucker S, Bowen WD, Iverson SJ (2007) Dimensions of diet segregation in grey seals Halichoerus grypus revealed through stable isotopes of carbon $\left(\delta^{13} \mathrm{C}\right)$ and nitrogen $\left(\delta^{15} \mathrm{~N}\right)$. Mar Ecol Prog Ser 339:271-282

- Villegas-Amtmann S, Costa DP, Tremblay Y, Salazar S, Aurioles-Gamboa D (2008) Multiple foraging strategies in a marine apex predator, the Galapagos sea lion Zalophus wollebaeki. Mar Ecol Prog Ser 363:299-309

Vlieg P (1984) Proximate analysis of commercial New Zealand fish species. 2. NZ J Sci 27:427-433

Waite AM, Muhling BA, Holl CM, Beckley LE and others (2007) Food web structure in two counter-rotating eddies based on $\delta^{15} \mathrm{~N}$ and $\delta^{13} \mathrm{C}$ isotopic analyses. Deep-Sea Res II 54:1055-1075

Walsh C, Mac Nally R (2003) The hier.part package, Version 0.5-1. Hierarchical partitioning. Documentation for R. R project for statistical computing, Vienna. http://cranr.rproject.org

Weise MJ, Harvey JT, Costa DP (2010) The role of body size in individual-based foraging strategies of a top marine predator. Ecology 91:1004-1015

Williams H, Pullen G (1993) Schooling behavior of jack mackerel, Trachurus declivis (Jenyns), observed in the Tasmanian purse seine fishery. Aust J Mar Freshw Res 44:577-587

Winship AJ, Trites AW, Rosen DAS (2002) A bioenergetic model for estimating the food requirements of Steller sea lions Eumetopias jubatus in Alaska, USA. Mar Ecol Prog Ser 229:291-312

Zar JH (1984) Biostatistical analysis. Prentice-Hall, Englewood Cliffs, NJ

Submitted: August 27, 2010; Accepted: November 14, 2010

Proofs received from author(s): January 23, 2011 